\title{
Characterization and ex vivo expansion of human placenta-derived natural killer cells for cancer immunotherapy
}

\section{Lin Kang ${ }^{1}$, Vanessa Voskinarian-Berse ${ }^{1}$, Eric Law ${ }^{1}$, Tiffany Reddin ${ }^{1}$, Mohit Bhatia ${ }^{1}$, Alexandra Hariri ${ }^{2}$, Yuhong Ning ${ }^{3}$, David Dong ${ }^{4}$, Timothy Maguire ${ }^{4}$, Martin Yarmush ${ }^{4}$, Wolfgang Hofgartner ${ }^{1}$, Stewart Abbot ${ }^{1}$, Xiaokui Zhang ${ }^{1 *}$ and Robert Hariri ${ }^{1}$}

\author{
${ }^{1}$ Celgene Cellular Therapeutics, Warren, NJ, USA \\ 2 Princeton University, Princeton, NJ, USA \\ ${ }^{3}$ Celgene Signal Research, San Diego, CA, USA \\ ${ }^{4}$ Department of Biomedical Engineering, Rutgers University, Piscataway, NJ, USA
}

Edited by:

Eric Vivier, Centre d'Immunologie de

Marseille-Luminy, France

Reviewed by:

Akira Shibuya, University of Tsukuba, Japan

Hugh T. Reyburn, Spanish National Research Council, Spain

*Correspondence:

Xiaokui Zhang, Celgene Cellular

Therapeutics, 33 Technology Drive,

Warren, NJ 07059, USA.

e-mail: xzhang@celgene.com
Recent clinical studies suggest that adoptive transfer of donor-derived natural killer (NK) cells may improve clinical outcome in hematological malignancies and some solid tumors by direct anti-tumor effects as well as by reduction of graft versus host disease (GVHD). NK cells have also been shown to enhance transplant engraftment during allogeneic hematopoietic stem cell transplantation (HSCT) for hematological malignancies. The limited ex vivo expansion potential of NK cells from peripheral blood (PB) or umbilical cord blood (UCB) has however restricted their therapeutic potential. Here we define methods to efficiently generate NK cells from donor-matched, full-term human placenta perfusate (termed Human Placenta-Derived Stem Cell, HPDSC) and UCB. Following isolation from cryopreserved donor-matched HPDSC and UCB units, CD56+CD3- placenta-derived NK cells, termed pNK cells, were expanded in culture for up to 3 weeks to yield an average of 1.2 billion cells per donor that were $>80 \%$ CD56+CD3-, comparable to doses previously utilized in clinical applications. Ex vivo-expanded pNK cells exhibited a marked increase in antitumor cytolytic activity coinciding with the significantly increased expression of NKG2D, NKp46, and NKp44 ( $p<0.001, p<0.001$, and $p<0.05$, respectively). Strong cytolytic activity was observed against a wide range of tumor cell lines in vitro. pNK cells display a distinct microRNA (miRNA) expression profile, immunophenotype, and greater anti-tumor capacity in vitro compared to PB NK cells used in recent clinical trials. With further development, pNK may represent a novel and effective cellular immunotherapy for patients with high clinical needs and few other therapeutic options.

Keywords: placental-derived natural killer cells, ex vivo expansion, anti-tumor cytolytic activity, miRNA, cellular immunotherapy

\section{INTRODUCTION}

The critical role of natural killer (NK) cells in the defense against cancer and virus infection has been increasingly appreciated since they were first discovered in mice more than 30 years ago (Herberman et al., 1975a,b). Clinical studies exploring the biological activities of NK cells in the treatment of malignant disease and during allogeneic hematopoietic stem cell transplantation (HSCT) have provided promising results. Transplant studies have suggested alloreactive NK cells could mediate potent anti-leukemia effects without causing graft versus host disease (GVHD). In human leukocyte antigen (HLA)-mismatched, haploidentical allogeneic stem cell transplants (SCT), NK alloreactivity was associated with a higher rate of survival, a lower rate of relapse, and treatment related mortality post transplantation (Ruggeri et al., 1999, 2002; Velardi et al., 2002). Several clinical studies have convincingly demonstrated that adoptive transfer of NK cells isolated from peripheral blood $(\mathrm{PB})$ of haploidentical donors can be successfully used for immunotherapy in acute myeloid leukemia (AML) patients
(Miller et al., 2005; Rubnitz et al., 2010; Curti et al., 2011). However, a number of technical challenges have hampered the widespread application of NK cells in immunotherapy; these include a limited ability to generate large numbers of effector cells, difficulty in maintaining high tumoricidal activity during ex vivo expansion and in vivo therapy, and a limited understanding of NK-specific tumor targeting profiles. Therefore, there is a need to overcome these challenges and enable a NK cell-based anti-tumor strategy in the clinic.

To date, the most utilized source for NK cells in adoptive immunotherapy is PB (Sutlu and Alici, 2009), with clinically effective doses reported in the range of $1 \times 10^{6}-9.3 \times 10^{6} \mathrm{~PB} \mathrm{NK}$ cells/kg (Passweg et al., 2004; Miller et al., 2005; McKenna et al., 2007; Shi et al., 2008; Meyer-Monard et al., 2009; Rubnitz et al., 2010; Yoon et al., 2010; Curti et al., 2011). Embryonic stem cells (Woll et al., 2009) and umbilical cord blood (UCB) (Spanholtz et al., 2010) have also been used as sources of CD34+ cells that were differentiated into functional NK cells. Previous studies have 
highlighted the potential to selectively isolate and expand NK cells from UCB for adoptive cell transfer treatment of tumors (Xing et al., 2010). Over the last decade the phenotype and function of decidual NK ( dNK) cells in placenta development have been studied extensively (Koopman et al., 2003; Hiby et al., 2004; Kopcow et al., 2005, 2010; Apps et al., 2011; Male et al., 2011). However, little information is available on the role of NK cells from placenta for cellular immunotherapy.

Recently, human placenta has been demonstrated as a novel and valuable source of multipotential stem/progenitor cells of mesenchymal and hematopoietic origin for multiple therapeutic applications (Parolini et al., 2008; Prather et al., 2008). Celgene Cellular Therapeutics (CCT, a division of Celgene Corporation) is developing human placenta-derived stem cells (HPDSC) as an adjunct to UCB cells for allogeneic use in first-degree or seconddegree blood relatives for augmentation of the stem cell graft in hematopoietic reconstitution. We have established a standardized procedure to perfuse donated full-term placentas with normal saline to recover HPDSC. HPDSC were subsequently processed to remove red blood cells, non-viable cells and tissue debris followed by cryopreservation. HPDSC were neither expanded nor cultured during processing. The process typically yields $100-500$ million total nucleated cells (TNC), approximately $1-5 \%$ of which are CD34+ hematopoietic stem cells (HSCs). We hypothesize that HPDSC combined with the donor-matched UCB could represent an effective new source of NK cells that holds potential for further immunotherapeutic development.

Unlike their antigen-specific lymphoid counterparts, such as T cells and B cells, NK cells, characterized as CD56+CD3-, recognize and subsequently kill virus-infected and transformed cells without prior immunization. NK cells operate via the balance of signals from inhibitory receptors, such as the killer cell immunoglobulin-like receptors (KIRs), and the C-type lectin family receptor: CD94/NKG2, with activating receptors, such as NKG2D, NKp46, NKp44, NKp30, and CD226 (Smyth et al., 2002; Huntington et al., 2007). Two major subtypes of CD56+ NK cells can be distinguished according to the co-expression of the cell surface marker CD16 (Jacobs et al., 2001). It has been demonstrated that CD56+CD16- NK cells have very few cytolytic granules, low or no expression of KIRs, high expression of KLR family members and are capable of producing cytokines and chemokines upon activation. CD56+CD16 + NK cells have abundant cytolytic granules and high expression of KIRs. PB contains more than $90 \%$ CD56+CD16+ NK cells, while more than $90 \%$ of $\mathrm{NK}$ cells in lymph nodes do not express CD16 (Cooper et al., 2001; Fehniger et al., 2003). Results from developmental NK cells studies suggest that the CD56+CD16+ NK cells are derived from the CD56+CD16- NK cells (Lanier et al., 1986; Ferlazzo et al., 2004; Freud et al., 2005). In addition to cell surface markers, different miRNA expression profiles have been associated with NK cell development, maturation, and function (Bezman et al., 2010). To date, no study has investigated the miRNA profile starting from donor-matched HPDSC and UCB (hereafter referred to as "Combo unit") followed by differentiation into functional NK cells.

In this study, we report that placenta is a rich source of placentaderived NK ( $\mathrm{pNK}$ ) cells that can be readily isolated from Combo units, followed by ex vivo expansion. We evaluated the proliferation, immunophenotype, miRNA expression, and activation of these expanded cells, as well as their cytolytic activities in vitro. Our results demonstrate that pNK cells can be generated in clinically relevant quantities and may be developed as a highly cytotoxic cellular product that can be used to treat a wide range of cancers.

\section{MATERIALS AND METHODS PROCESSING OF HPDSC AND UCB}

Postpartum placentas and umbilical cords were procured under full-informed consent of donors with donor eligibility documentation, and were qualified using a series of tests, including serology, bacteriology, and HLA typing. HPDSC isolation and recovery was achieved by cannulation of the umbilical vessels (two arteries and one vein) under sterile conditions with polyethylene catheters connected to a flow-controlled fluid circuit allowing perfusion of the placenta. A total of $750 \mathrm{ml}$ of perfusion solution $(0.9 \% \mathrm{NaCl}$ injection solution USP Grade) (VWR) was collected from each placenta. UCB was obtained by cannulation of the umbilical vein and collected into a bag containing citrate-phosphate-dextrose (Fenwal). Both UCB and perfusate were then processed by red blood cell depletion using Hetastarch, followed by volume reduction. The resulting cell populations were cryopreserved in a solution containing 5\% human albumin and 10\% DMSO with a controlled rate freezer prior to final storage in the gas phase of a liquid nitrogen tank.

\section{ISOLATION OF pNK CELLS FROM HPDSC AND UCB}

The donor-matched cryopreserved HPDSC and UCB were initially thawed, combined, and washed with RPMI 1640 (without phenol red) (Gibco) containing 5\% v/v fetal bovine serum (FBS; Hyclone Laboratories). In some NK cell expansion studies, peripheral blood mononuclear cells (PBMCs) obtained from buffy coat (Blood Center, NJ, USA) were prepared as an alternate source of NK cells. After washing, cell pellets were resuspended at $5 \times 10^{7}$ cells/ml in RoboSep buffer (StemCell Technologies). DNase I $(0.1 \mathrm{mg} / \mathrm{ml}$ solution) (StemCell Technologies) was added to the cell suspension to a final concentration of $100 \mu \mathrm{l} / \mathrm{ml}$, mixed gently by pipetting and incubated for $15 \mathrm{~min}$ at room temperature (RT) prior to isolation of NK cells using the EasySep ${ }^{\circledR} \mathrm{NK}$ Cell Enrichment Kit (StemCell Technologies). Human NK Cell Enrichment Cocktail (containing monoclonal antibodies to human cell surface antigens CD3, CD4, CD14, CD19, CD20, CD36, CD66b, CD123, HLA-DR, and glycophorin A) was added to the cell suspension at a final concentration of $50 \mu \mathrm{l} / \mathrm{ml}$ and incubated for $10 \mathrm{~min}$ at RT. After incubation with EasySep ${ }^{\circledR}$ Magnetic Microparticles (final concentration of $100 \mu \mathrm{l} / \mathrm{ml}$ ) for $5 \mathrm{~min}$ at RT, enrichment of NK cells was performed according to the protocol provided by the manufacturer (StemCell Technologies). A CD56+CD3population was thus collected and ready for further analysis or cultivation. The following equation was used for the calculation of the recovery of pNK cells: (purified NK cell count $\times$ purified $\mathrm{CD} 56+\mathrm{CD} 3-\%) /(\mathrm{TNC}$ count $\times$ starting CD56+CD3-\% $)$.

\section{EX VIVO EXPANSION OF PNK CELLS}

Enriched placental CD56+CD3 - NK cells were cultured in Start Medium based on a modification of previously described protocols (Yssel et al., 1984). All components were from Sigma-Aldrich 
unless otherwise specified. Briefly, Start Medium was composed of Iscove's Modified Dulbecco's Media (IMDM) (ATCC) supplemented with $10 \%$ FBS (Hyclone), $35 \mathrm{mg} / \mathrm{ml}$ transferrin, $5 \mu \mathrm{g} / \mathrm{ml}$ insulin, $20 \mu \mathrm{M}$ ethanolamine, $1 \mu \mathrm{g} / \mathrm{ml}$ oleic acid, $1 \mu \mathrm{g} / \mathrm{ml}$ linoleic acid, $0.2 \mu \mathrm{g} / \mathrm{ml}$ palmitic acid, $2.5 \mu \mathrm{g} / \mathrm{ml}$ bovine serum albumin (BSA), and $0.1 \mu \mathrm{g} / \mathrm{ml}$ Phytohemagglutinin (PHA-P). NK cells were resuspended at approximately $2.5 \times 10^{5} / \mathrm{ml}$ in Start Medium plus Penicillin-Streptomycin (Invitrogen) and $200 \mathrm{IU} / \mathrm{ml}$ IL-2 (R\&D Systems). Mitomycin C-treated PBMC and K562 (ATCC) cells were added together to Start Medium as feeder cells at a final concentration of $1 \times 10^{6} / \mathrm{ml}$ each. To initiate NK cell expansion, the feeder cells and NK cell suspension was transferred into a gas permeable culture bag (American Fluoroseal) and was cultured in an incubator at $37^{\circ} \mathrm{C}$ in $5 \% \mathrm{CO}_{2}$. After culturing for 5-7 days, expanded cell populations were fed with Maintenance Medium for up to 21 days. Maintenance Medium was composed of IMDM supplemented with 10\% FBS, 2\% Human AB serum (Gemini), Penicillin-Streptomycin, and $200 \mathrm{IU} / \mathrm{ml}$ IL-2. Total cell number and cell viability were assessed using EasyCount (Immunicon) and EasyCount ViaSure Kit (Immunicon). Fold expansion was calculated using the absolute number of CD56+CD3 - NK cells on Day 21/absolute number of NK cells on Day 0.

\section{BRDU/7-AAD CELL CYCLE ANALYSIS}

Expanded cells at different time points as indicated were labeled with 5-bromo-2'-deoxyuridine (BrdU) (BD Bioscience) and cultured at $37^{\circ} \mathrm{C}$ in $5 \% \mathrm{CO}_{2}$ for $24 \mathrm{~h}$. The cells were harvested, fixed, and stained with anti-BrdU and 7-aminoactinomycin-D (7-AAD) following the protocol provided by the manufacturer. The cell cycle data was collected via FACSCalibur (BD Biosciences), and analysis was accomplished with FlowJo (Tree Star, Inc.).

\section{IMMUNOPHENOTYPIC CHARACTERIZATION}

The phenotype of mononuclear cells (MNCs) or enriched NK cells from Combo unit, or expanded cells from Day 7, 14, 21 cultures, was analyzed by multi-color flow cytometry. Cells were stained with fluorochrome-conjugated monoclonal antibodies against human blood surface antigens: CD56-PerCP/-PE/PE-Cy7, CD3-FITC/-APC-Cy7, CD16-FITC/-PerCP, CD158bPE (KIR2DL2/2DL3), CD158e1-PE (KIR3DL1), NKG2D-APC, NKp46-APC, NKp44-PE, NKp30-PE, CD226-PE, 2B4-PE (all purchased from BD Biosciences Pharmingen), and CD94-PE (R\&D Systems). All analyses were performed using FACSCanto I (BD Biosciences) and FlowJo analysis software.

\section{PKH26/TO-PRO-3 CYTOTOXICITY ASSAY}

Natural killer cell in vitro cytotoxicity was examined using NK cells as effector cells and various tumor cell lines as target cells. Target cells were labeled with PKH26 (Sigma-Aldrich) (Lee-MacAry et al., 2001; Ferlazzo et al., 2004), placed in 96-well U-bottom tissue culture plates and incubated with effector cells at various effector to target (E:T) ratios in $200 \mu \mathrm{l}$ RPMI 1640 supplemented with $10 \%$ FBS. After $4 \mathrm{~h}$ incubation at $37^{\circ} \mathrm{C}$ in $5 \% \mathrm{CO}_{2}$, cells were harvested and TO-PRO-3 (Invitrogen) was added to cultures at $1 \mu \mathrm{M}$ final concentration followed by FACS analysis using BD FACSCanto I. Cytotoxicity was expressed as the percentage of dead cells (PKH26+TO-PRO-3+) within the total PKH26+ target tumor cells.

\section{LACTATE DEHYDROGENASE RELEASE ASSAY}

Alternatively, NK cell in vitro cytotoxicity was examined by lactate dehydrogenase (LDH) release assay using CYTOTOX 96 ${ }^{\circledR}$ colorimetric cytotoxicity assay kit (Promega). In this assay, effector cells and target cells were placed in 96-well U-bottom tissue culture plates and incubated at various E:T ratios in $100 \mu \mathrm{l} \mathrm{RPMI}$ 1640 without phenol red (Invitrogen) supplemented with $2 \%$ human $\mathrm{AB}$ serum and incubated for $4 \mathrm{~h}$ at $37^{\circ} \mathrm{C}$ in $5 \% \mathrm{CO}_{2}$. After incubation, $50 \mu \mathrm{l}$ supernatant was transferred to the enzymatic assay plate for detection of LDH activity as instructed by the manufacturer. Cytotoxicity was calculated using the following equation: \% Cytotoxicity $=($ experimental release - effector spontaneous release - target spontaneous release)/(target maximum release - target spontaneous release) $\times 100$.

\section{miRNA PREPARATION AND QUANTITATIVE PCR}

MicroRNA was isolated from 0.5 to $1.5 \times 10^{6}$ cells using a MIR$\mathrm{VANA}^{\mathrm{TM}}$ miRNA Isolation Kit (Ambion) following the protocol provided by manufacturer. The concentration and purity of the recovered small RNA was determined by measuring its absorbance at 260 and $280 \mathrm{~nm}$. Purified RNA samples were subjected to cDNA synthesis using TAQMAN ${ }^{\circledR}$ Reverse Transcription Reagents (Applied Biosystems) followed by real-time PCR analysis by the 7900HT Fast Real-Time PCR System. Human miRNA Arrays (Applied Biosystems) were used for gene expression profiling and miRNA profiling. For each miRNA, the mean $\Delta \mathrm{Ct}$ from real-time PCR was calculated as $\Delta \mathrm{Ct}_{\text {mean }}=\operatorname{mean}\left(\mathrm{Ct}_{\text {sample }}\right)-\operatorname{mean}\left(\mathrm{Ct}_{\text {endo }}\right)$, where $\mathrm{Ct}_{\text {sample }}$ is the $\mathrm{Ct}$ value of a miRNA and $\mathrm{Ct}_{\text {endo }}$ is the $\mathrm{Ct}$ value of the endogenous control. miRNAs were unique to $\mathrm{pNK}$ or PB NK if they met the following criteria: (i) $\Delta \mathrm{Ct}_{\text {mean }}<0$, (ii) $\left|\Delta \mathrm{Ct}_{\text {mean }}\right| \geq 2 \times \mathrm{Ct}_{\text {endo_sD }}$, where $\left|\Delta \mathrm{Ct}_{\text {mean }}\right|$ is the absolute value of $\Delta \mathrm{Ct}_{\text {mean }}$ and $\mathrm{Ct}_{\text {endo_sD }}$ is the standard deviation of the $\mathrm{Ct}_{\text {endo }}$, and (iii) the miRNAs that satisfied the previous two criteria were exclusive to the cell type. The rationale for using the aforementioned criteria was to confirm that a miRNA is abundant in at least one donor sample, in comparison to the endogenous control. Donor samples without detectable levels of a miRNA were numerically ignored when averaging the $\mathrm{Ct}$ values. A negative $\Delta \mathrm{Ct}_{\text {mean }}$ along with two standard deviations from the control gene ensures that the particular gene is relatively abundant. Additionally, all of the standard deviations of the reference genes were less than 0.25 , which confirms the quality of the control. Significantly expressed miRNAs between $\mathrm{pNK}$ and $\mathrm{PB} \mathrm{NK}$, as well those between Day 0 pNK and Day 21 pNK were determined by a two-sample $t$-test ( $p$ value of 0.01 significance level) on the $\Delta \mathrm{Ct}$ values. Expression fold changes were calculated according to $R=2^{\text {( } \Delta \mathrm{Ct} 1 \_ \text {mean }-\Delta \mathrm{Ct} 2 \_ \text {mean) }}$ where $R$ is the fold change (Livak and Schmittgen, 2001); $\Delta \mathrm{Ct1} \_$mean is the average $\Delta \mathrm{Ct}$ of $\mathrm{pNK}$ on Day 0 , and $\Delta \mathrm{Ct} 2 \_$mean is the average $\Delta \mathrm{Ct}$ of PB NK or expanded $\mathrm{pNK}$.

\section{mIRNA TARGET PREDICTION AND PATHWAY ANALYSIS}

A search for miRNAs that were unique to either PB NK and $\mathrm{pNK}$, as well as those that were highly expressed in expanded pNK, was conducted within seven miRNA target gene prediction databases (Diana-microT, miRDB, miRTar, microRNA.org, MicroCosmTargets, picTar, and TargetScan) and three experimentally validated target gene databases (TarBase, miRecords, and miRTarBase) by 
using medium to high stringency search criteria. Genes that were predicted by five or more databases were considered as high confidence targets. Such targeted genes were then examined in pathway analysis (Ingenuity Systems) in order to determine the associated signaling pathways and cellular functions. Pathways were scored and ranked based on their $p$-values.

\section{RESULTS}

\section{PHENOTYPIC PROFILE OF HPDSC NK CELLS}

Human placenta-derived stem cells was harvested from three placentas separately and analyzed for cell surface markers by flow cytometry and compared to the donor-matched UCB. The composition of NK cells identified by CD56+CD3- expression was not substantially different between HPDSC $(0.70 \pm 0.24 \%)$ and the donor-matched UCB $(0.63 \pm 0.36 \%)(n=3)$. The CD56+CD3$\mathrm{NK}$ cells were then examined in greater detail using fluorescenceconjugated monoclonal antibodies against specific NK receptors. The two-sample $t$-test was used to determine if population means were equal in HPDSC and UCB. As shown in Figure 1A, NK cells from three pairs of donor-matched HPDSC and UCB units exhibited phenotypic similarities, with no significant differences in expression of sub-populations such as CD56+CD16-, CD56+CD16+, NKG2D, CD94, KIR3DL1, and KIR2DL2/L3. After NK expansion for 21 days separately, HPDSC NK, and UCB NK cells showed comparable cytotoxicity against K562 cells at various $\mathrm{E}: \mathrm{T}$ ratios, indicating functional similarity between HPDSC and UCB NK cells after expansion (Figure 1B).

Based on these similar phenotypic and functional characteristics and in order to increase the starting cell number, HPDSC and donor-matched UCB units were combined into one Combo unit, to be used as the starting material for further cell expansion.

\section{ISOLATION AND CHARACTERIZATION OF PNK FROM CRYOPRESERVED COMBO UNITS}

To qualify $\mathrm{pNK}$ as a reliable feed stock for this study and for future clinical production, a series of NK cell isolation experiments were performed to evaluate the consistency of recovery of pNK cells from the cryopreserved Combo units. Among 30 isolation procedures performed, an average number of $1.5 \times 10^{7} \mathrm{pNK}$ cells were recovered, enriching the abundance of CD56+ CD3 - cells approximately 25 -fold ( $71 \%$ compared to $3 \%$ in the starting material) (Table 1; Figures 2B,C). Our results indicated nearly 90\% recovery of pNK cells from the cryopreserved Combo units.

To compare pNK cells to PB NK cells, pNK cells from 16 Combo units and NK cells from 13 units of buffy coat obtained from $\mathrm{PB}$ were subjected to an extensive immunophenotypic characterization. The expression of cell surface markers, including KIRs (KIR3DL1, KIR2DL2/3), CD94, NKG2D, natural cytotoxicity receptors NCRs (NKp46, NKp44, and NKp30), 2B4, and CD226 was evaluated. Significant differences were observed in 7 out of 11 sub-populations, including CD56+CD16-, CD56+CD16+, KIR2DL2/3+, NKp46+, NKp30+, 2B4+, and CD94+ (Figure 2A; Table 2). Notably, most (79\%) of the PB NK cells displayed the mature CD56+CD16+ phenotype, while a majority of the $\mathrm{pNK}$ population ( $>60 \%$ ) were immature CD56+CD16- cells.

In attempts to compare gene expression profiles in pNK cells to $\mathrm{PB}$ NK cells, we discovered that individual donor variations

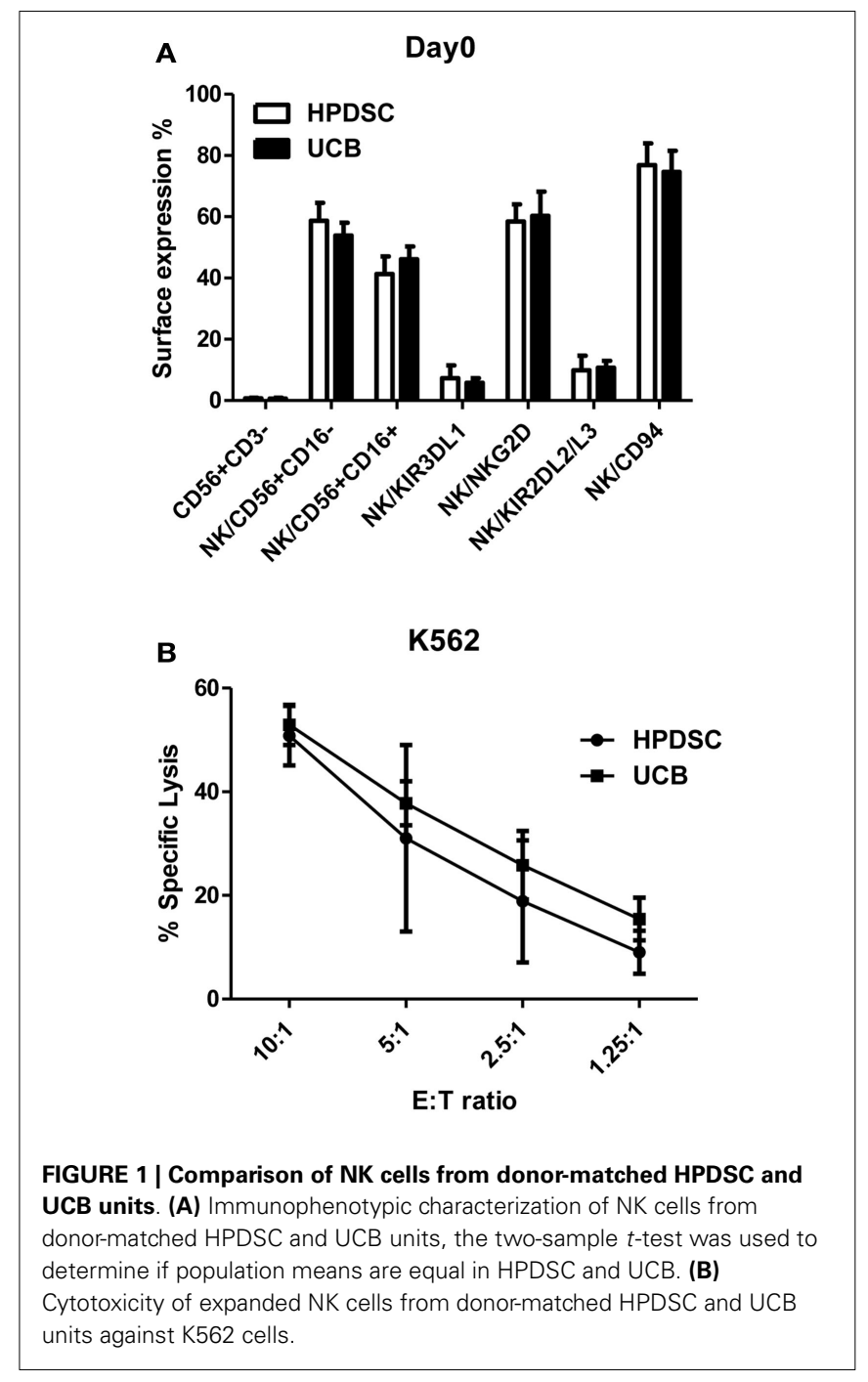

Table 1 | NK cell isolation from 30 cryopreserved Combo units.

\begin{tabular}{lllll}
\hline & $\begin{array}{l}\text { Starting } \\
\text { TNC count }\end{array}$ & $\begin{array}{l}\text { Purified } \\
\text { NK cell count }\end{array}$ & \multicolumn{2}{l}{$\begin{array}{l}\text { Purity } \\
\text { (\% CD56+CD3) }\end{array}$} \\
\cline { 4 - 5 } & & & Starting & Purified \\
\hline Range (min, max) & $4.90 \mathrm{E}+07$, & $3.97 \mathrm{E}+05$, & 0.56, & 23.1 \\
& $9.76 \mathrm{E}+08$ & $5.90 \mathrm{E}+07$ & 13.9 & 89.1 \\
Median & $3.80 \mathrm{E}+08$ & $1.02 \mathrm{E}+07$ & 2.40 & 79.80 \\
Average & $3.95 \mathrm{E}+08$ & $1.46 \mathrm{E}+07$ & 2.88 & 71.18 \\
SD & $2.46 \mathrm{E}+08$ & $1.36 \mathrm{E}+07$ & 2.63 & 20.86 \\
\hline
\end{tabular}

$S D$, standard deviation.

in gene expression profiles were too large to evaluate differences between the placenta and PB NK sources. As an alternative strategy, differences were further explored by miRNA analysis using TaqMan Array Human MicroRNA Cards to compare expression of 365 miRNAs in pNK and PB NK cells. These analyses identified four miRNAs unique to pNK cells (has-miR-337, 


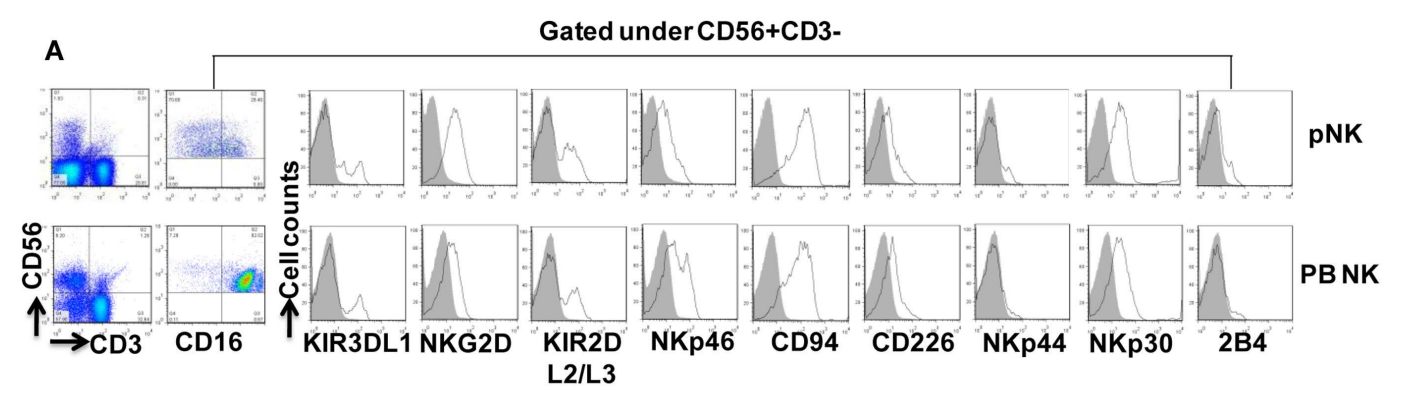

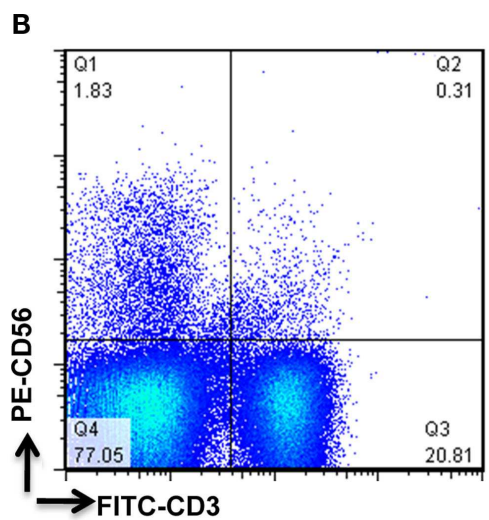

FIGURE 2 | Phenotypic characterization of pNK cells in comparison with PB NK cells. (A) Flow cytometric identification of NK cells from Combo unit and PB. CD56+CD3- gated NK cells expressed a repertoire of receptors important for regulating NK-cell activity, including CD16, KIR3DL1, NKG2D,

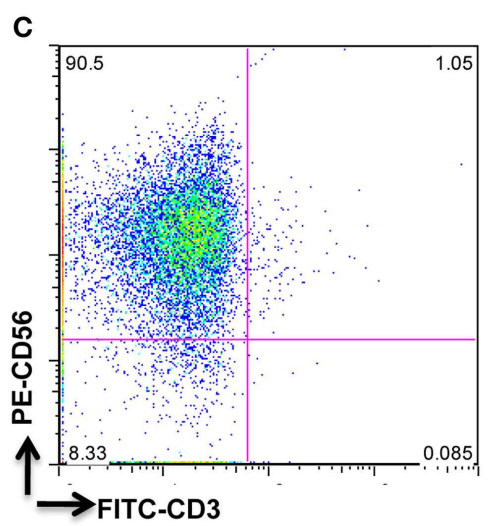

KIR2DL2/L3, NKp46, CD94, CD226, NKp44, NKp30, and 2B4. (B) Percentage of CD56+CD3 - pNK cells from Combo unit prior to NK cell isolation. (C) About 90\% CD56+CD3- NK cells from Combo unit was achieved after NK cell isolation.
Table 2 | Comparison of sub-populations within pNK and PB NK cell phenotype.

\begin{tabular}{|c|c|c|c|c|c|}
\hline \multirow[t]{2}{*}{ NK sub-populations } & \multicolumn{2}{|c|}{ Combo $(n=16 U)$} & \multicolumn{2}{|c|}{$\mathrm{PB}(n=13 \mathrm{U})$} & \multirow[t]{2}{*}{$p$ Value } \\
\hline & Mean (\%) & SD & Mean \% & SD & \\
\hline CD16- & 60.94 & 16.58 & 21.38 & 14.00 & $* * *$ \\
\hline CD16+ & 39.05 & 16.58 & 78.63 & 14.01 & $* * *$ \\
\hline KIR3DL1+ & 12.31 & 8.11 & 7.07 & 8.28 & NS \\
\hline KIR2DL2/L3+ & 21.89 & 8.65 & 9.46 & 11.31 & ** \\
\hline $\mathrm{NKG} 2 \mathrm{D}+$ & 42.11 & 17.79 & 29.88 & 22.64 & NS \\
\hline NKp46+ & 6.98 & 4.33 & 18.86 & 13.97 & * \\
\hline CD226+ & 15.97 & 6.66 & 26.75 & 23.31 & NS \\
\hline NKp44+ & 9.48 & 5.27 & 4.89 & 6.40 & NS \\
\hline NKp30+ & 39.08 & 19.06 & 18.99 & 20.86 & ** \\
\hline 2B4+ & 11.07 & 5.90 & 4.46 & 6.45 & * \\
\hline CD94+ & 71.31 & 13.94 & 26.17 & 30.49 & $* * *$ \\
\hline
\end{tabular}

NS, not significant; ${ }^{*} p<0.05 ;{ }^{* *} p<0.01 ;{ }^{* *} p<0.001$.

has-miR-422a, has-miR-549, and has-miR-618) and eight miRNAs uniquely expressed by PB NK cells (has-let-7b, has-miR-146b, hasmiR-19b, has-miR-24, has-miR-347, has-miR-381, has-miR-517c, and has-miR-631). The pNK-unique miRNAs have not been well characterized except hsa-miR-337, which has been associated with chondrogenesis as a regulator of TGFBR2 expression (Zhong et al., 2012). Additionally, 20 miRNAs were expressed at a significantly higher level, and 29 miRNAs were expressed at a significantly lower level in pNK cells compared to PB NK cells (Tables 3 and 4). Target gene prediction analysis returned 14 highly expressed miRNAs in pNK and 24 highly expressed miRNA in PB NK with more than one target gene (Table 5). Thus PB NK cells and pNK cells display distinct miRNA expression patterns.

\section{EX VIVO EXPANSION OF pNK CELLS}

Starting from an average of 10 million pNK cells after isolation procedures, we attempted a series of optimizations of the pNK cell expansion process based on a previously described protocol for expansion of cytotoxic and helper T cells (Yssel et al., 1984). First, to optimize the feeder cell concentration, K562 cells and allogeneic PBMCs were tested at ratios of, 1:10, 1:5, and 1:1 (K562: PBMC), with the concentration of PBMC fixed at $1 \times 10^{6} / \mathrm{ml}$. As

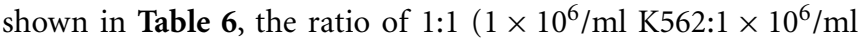
PBMC) resulted in the greatest NK cell expansion of 98 -fold $(n=14)$, compared to 32 -fold $(n=3)$ for the 1:5 ratio and 53 -fold $(n=9)$ for the 1:10 ratio. Therefore the 1:1 ratio was used for further pNK cultivation. Next, we tested whether replenishing with fresh feeder cells could further enhance NK expansion during the cultivation process. To determine the optimal time window for replenishing with fresh feeder cells, cell growth kinetics of pNK cells at Day 7, 14, 21, and 28 were evaluated with BrdU/7-AAD 
Table 3 | Highly expressed miRNAs in pNK cells.

\begin{tabular}{lrr}
\hline miRNA & Fold increase in pNK & $\boldsymbol{p}$ Value \\
\hline hsa-miR-211 & 5.26 & $6.73 \mathrm{E}-03$ \\
hsa-miR-520c & 5.58 & $7.70 \mathrm{E}-03$ \\
hsa-miR-125b & 7.46 & $9.26 \mathrm{E}-04$ \\
hsa-miR-100 & 11.19 & $4.29 \mathrm{E}-04$ \\
hsa-miR-326 & 14.50 & $5.05 \mathrm{E}-05$ \\
hsa-miR-519c & 18.74 & $6.32 \mathrm{E}-03$ \\
hsa-miR-515-5p & 20.99 & $6.88 \mathrm{E}-03$ \\
hsa-miR-450 & 21.31 & $3.00 \mathrm{E}-03$ \\
hsa-miR-198 & 27.97 & $3.41 \mathrm{E}-04$ \\
hsa-miR-522 & 33.63 & $2.56 \mathrm{E}-03$ \\
hsa-miR-518e & 39.78 & $7.17 \mathrm{E}-03$ \\
hsa-miR-497 & 54.47 & $8.88 \mathrm{E}-03$ \\
hsa-miR-566 & 75.98 & $1.32 \mathrm{E}-04$ \\
hsa-miR-519d & 96.65 & $3.47 \mathrm{E}-04$ \\
hsa-miR-627 & 98.54 & $3.42 \mathrm{E}-04$ \\
hsa-miR-524 & 106.36 & $7.97 \mathrm{E}-04$ \\
hsa-miR-520g & 291.10 & $3.24 \mathrm{E}-04$ \\
hsa-miR-302c & 396.53 & $3.55 \mathrm{E}-04$ \\
hsa-miR-512-3p & 640.56 & $3.16 \mathrm{E}-05$ \\
hsa-miR-520h & 1793.82 & $9.60 \mathrm{E}-05$ \\
\hline
\end{tabular}

double-staining followed by flow cytometry. As seen in Figure 3, at Day 7, the majority of cultured NK cells were in S-phase, indicating that the cells were proliferating. The percentage of actively proliferating/dividing cells decreased substantially during subsequent culture, suggesting Day 7 was the optimal window for re-stimulation. As shown in the Table 7, addition of fresh K562 and PBMC feeder cells at Day 7 resulted in a threefold increase in expansion of NK cells. This optimized 21-day NK culture method was repeated in 20 expansion experiments, yielding an average of $1.2 \times 10^{9} \mathrm{CD} 56+\mathrm{CD} 3-\mathrm{NK}$ cells with around $80 \%$ viability (Figure 4A).

\section{CHARACTERIZATION OF EX VIVO-EXPANDED pNK CELLS}

Immunophenotypic and miRNA changes were characterized in expanded pNK cells from 12 Combo units in comparison to unexpanded cells. First, Day 21 pNK cells showed a significant increase in the expression of activating receptors such as NKG2D, NKp46, NKp44, and NKp30, and a significant decrease in the expression of bidirectional receptor 2B4. The expression of inhibitory KIRs, including KIR3DL1 and KIR2DL2/L3 was similar for expanded and unexpanded cells (Figure 4B; Table 8).

We have also investigated the immunophenotype of PB NK expanded using the optimized isolation and expansion procedure established for $\mathrm{pNK}$ in nine donors. Comparison studies of expanded PB NK cells to expanded pNK cells have revealed that the most profound difference was the lower expression of NKp44 (Table 9). Less cytotoxic activity was also observed with expanded PB NK cells at Day 21 (42 $\pm 7 \%$ ) (Figure 4C).

Moreover, Expression of 23 miRNAs was increased while 31 other miRNAs were downregulated after ex vivo expansion (Table 10). Interestingly, one of the miRNAs found to be upregulated was has-miR-155, which when overexpressed has been shown
Table 4 | Highly expressed miRNAs in PB NK cells.

\begin{tabular}{|c|c|c|}
\hline miRNA & Fold increase in PB NK & $p$ Value \\
\hline hsa-miR-331 & 1.43 & $5.33 E-03$ \\
\hline hsa-miR-186 & 1.90 & $4.54 \mathrm{E}-03$ \\
\hline hsa-miR-17-5p & 2.38 & $2.34 \mathrm{E}-03$ \\
\hline hsa-miR-26a & 2.66 & $2.36 \mathrm{E}-03$ \\
\hline hsa-miR-133b & 2.69 & $8.19 E-04$ \\
\hline hsa-miR-181b & 2.77 & $4.42 \mathrm{E}-03$ \\
\hline hsa-miR-222 & 2.83 & $5.76 \mathrm{E}-03$ \\
\hline hsa-miR-197 & 3.00 & $5.48 \mathrm{E}-05$ \\
\hline hsa-miR-146b & 3.05 & $2.92 \mathrm{E}-03$ \\
\hline hsa-miR-342 & 3.06 & $3.23 E-04$ \\
\hline hsa-miR-181d & 3.08 & $3.41 \mathrm{E}-03$ \\
\hline hsa-miR-155 & 3.12 & $8.24 \mathrm{E}-04$ \\
\hline hsa-miR-484 & 3.18 & $1.23 E-03$ \\
\hline hsa-let-7g & 3.18 & $2.08 \mathrm{E}-03$ \\
\hline hsa-miR-200c & 3.66 & $1.91 \mathrm{E}-03$ \\
\hline hsa-miR-181c & 3.83 & $2.72 \mathrm{E}-04$ \\
\hline hsa-miR-191 & 4.06 & $3.16 \mathrm{E}-04$ \\
\hline hsa-miR-596 & 4.14 & $7.06 \mathrm{E}-03$ \\
\hline hsa-miR-142-5p & 4.63 & $4.84 \mathrm{E}-04$ \\
\hline hsa-miR-95 & 4.86 & $2.99 \mathrm{E}-03$ \\
\hline hsa-let-7a & 5.04 & $3.91 \mathrm{E}-04$ \\
\hline hsa-miR-21 & 5.10 & $2.87 \mathrm{E}-04$ \\
\hline hsa-miR-152 & 5.46 & 1.76E-03 \\
\hline hsa-miR-642 & 5.56 & $4.70 \mathrm{E}-04$ \\
\hline hsa-miR-24 & 5.91 & $2.54 \mathrm{E}-05$ \\
\hline hsa-miR-10a & 14.56 & $5.71 \mathrm{E}-03$ \\
\hline hsa-miR-429 & 31.74 & $5.70 E-03$ \\
\hline hsa-let-7b & 108.34 & $4.66 \mathrm{E}-05$ \\
\hline hsa-miR-199b & 2819.55 & $3.05 E-03$ \\
\hline
\end{tabular}

to increase NK cell function via enhanced induction of IFN- $\gamma$ (Trotta et al., 2012).

The cytolytic activity of expanded pNK was evaluated in a FACS-based PKH26/TO-PRO-3 cytotoxicity assay against K562 cells. As shown in Figure 4C, while unexpanded pNK cells showed minimal cytolytic activity, there was a significant enhancement of cytotoxicity against K562 cells by pNK cells at Day 21 versus Day 14 at an E:T ratio of 10:1 (63 $\pm 15 \%$ versus $45 \pm 4 \%, p<0.001)$. The increase in cytolytic activity after 21-day expansion was associated with the increased expression in activating receptors (Table 8) and miRNAs (Table 10). Extended cultivation to 28 days did not result in further increases in activity.

IN VITRO ANTI-TUMOR CYTOLYTIC ACTIVITY OF EXPANDED PNK CELLS To further evaluate expanded pNK cell activity against a range of tumor types, 11 additional tumor cells lines were co-cultured with Day 21 expanded pNK cells, and NK cell cytolytic activity was measured at E:T ratios of 10:1, 5:1, 2:1, and 1:1 in a $4-\mathrm{h} \mathrm{LDH} \mathrm{release}$ assay. At an E:T ratio of 10:1, expanded pNK cells exhibited greater than $50 \%$ cytotoxicity against multiple tumor cell lines, including U937 (89.2 $\pm 9.8 \%)$, WERI-RB-1 (73.3 $\pm 11.8 \%)$, RPMI8226 $(61.3 \% \pm 1.3 \%), \mathrm{HCT}-116(61 \pm 5.1 \%)$, U266 $(57.4 \pm 4.7 \%)$, as well as and K562 cells $(88.6 \pm 5.6 \%)$ (Figure 5). Cytolytic activity 
Table 5 | Differentially regulated miRs and their validated target genes in pNK, compared to PB NK.

miR

HIGHLY EXPRESSED MIRNAS IN PB NK

hsa-let-7a

hsa-let-7g

hsa-miR-10a

hsa-miR-133b

hsa-miR-146b*

hsa-miR-152

hsa-miR-155

hsa-miR-181b

CYLD (2)

hsa-miR-181c

hsa-miR-181d

hsa-miR-186

hsa-miR-191
TRIM71 (7)

UHRF2 (5)

MED28 (4)

ZFP36L1 (1)

HMGA2 (6)

IGF2BP1 (5)

TMEM2 (5)

LIN28B (5)

CCNJ (5)

CDC34 (5)

IGF2BP2 (5)

DMD (5)

E2F6 (5)

HMGA1 (4)

PGRMC1 (4)

THBS1 (4)

PDE12 (4)

E2F5 (4)

HMGA2 (6)

NCOR2 (5)

BCL2L2 (3)

TRAF6 (7)

DNMT1 (5)

SOCS1 (5)

TSHZ3 (5)

HIVEP2 (5)

TAB2 (4)

JARID2 (4)

CEBPB (4)

ARID2 (4)

DHX40 (4)

PICALM (4)

TRIM32 (4)

ZIC3 (4)

KBTBD2 (4)

$\mathrm{MSH} 2$ (1)

E2F1 (1)

GRIA2 (4)

VSNL1 (1)

GATA6 (4)

GATA6 (3)

AKAP12 (1)

TMC7 (2)
HMGA2 (6)
Experimentally validated genes

$\begin{array}{llll}\text { LIN28A (3) } & \text { ACP1 (2) } & \text { E2F2 (2) } & \text { SMOX (1) } \\ \text { CASP3 (3) } & \text { RTCD1 (2) } & \text { ITGB3 (2) } & \text { MYC (1) } \\ \text { PRDM1 (2) } & \text { CCND2 (2) } & \text { LIN28 (1) } & \text { TUSC2 (1) } \\ \text { DICER1 (2) } & \text { SLC20A1 (2) } & \text { NF2 (1) } & \text { BCL2 (1) } \\ \text { EGR3 (1) } & \text { IL6 (1) } & \text { NEFM (1) } & \end{array}$

NKIRAS2 (1)

CDC25A (3) GRPEL2 (2)

AURKB (3)

$\mathrm{DH} \times 57$ (3)

FNDC3A (3)

$\mathrm{RDH} 10$ (3)

IL6 (1)

NEFM (1)

NXT2 (2)

EIF2C3 (2)

CCNA2 (2)

CCNF (2)

EDEM3 (2)

SLC25A24 (3)

SNAP23 (3)

LIN28A (3)

PRDM1 (3)

NRAS (3)

RRM2 (3)

CCND1 (2)

ATP6V1F (2)

MARS2 (2)

MRM1 (2)

POM121 (2)

PXDN (2)

TRABD (2)

SCYL1 (2)

PLAGL2 (2)

FARP1 (2)

C7ORF58 (2)

LIN28 (1)

BCL7A (1)

ACTG1 (1)

AARSD1 (1)

ANAPC1 (1)

CDIPT (1)

SLC25A13 (1)

CDKAL1 (1)

CSNK1D (1)

SLC25A1 (1)

UHRF1 (1)

DOCK5 (1)

C20ORF72 (1)

FADS2 (1)

SCAMP3 (1)

FAM96A (1)

C2ORF18 (1)

GPR56 (1)

IPO4 (1)

CIAO1 (1)

BIRC6 (1)

KIAA0409 (1)

AURKA (1)

NEDD4 (1)

OPRS1 (1)

ALG3 (1)

ARID3A (1)

CCBL2 (1)

RRP1B (1)

RHOG (1)

TAB2 (1)

COL1A2 (3)

SLC1A4 (1)

BCL2L1 (1)

EIF4G2 (5)

IGF2BP1 (5)

USF2 (1)

BTRC (1)

MCL1 (2)

IRAK1 (5)

MMP16 (2)

CARD10 (1)

HLA-G (2)

DET1 (4)

IKBKE (3)

PHF17 (3)

$\mathrm{BACH} 1$ (3)

RCN2 (3)

RCOR1 (3)

ZNF652 (3)

MYB (3)

TLE4 (3)

CSF1R (3)

FAR1 (3)

ZNF236 (3)

PELI1 (1)

SPI1 (3)

MEIS1 (2)

SMAD2 (2)

CYR61 (2)

TP53INP1 (2)

ANKFY1 (2)

CHAF1A (2)

CLDN1 (2)

MYO10 (2)

NARS (2)

PHC2 (2)

SDCBP (2)

SMAD1 (2)

TRAM1 (2)

TRIP13 (2)

FGF7 (2)

KRAS (2)

HIF1A (2)

C5ORF41 (2)

IKBIP (2)

TWF1 (2)

CUX1 (2)

SLA (2)

AGTR1 (1)

TM6SF1 (1)

FOXO3 (1)

ARL5B (1)

ATG3 (1)

ATP6V1C1 (1)

BET1 (1)

CBFB (1)

DNAJB1 (1)

DSG2 (1)

FMNL2 (1)

PKN2 (1)

PRAF2 (1)

RAB34 (1)

RAB6A (1)

SYPL1 (1)

VAMP3 (1)

WDFY1 (1)

ETS1 (1)

INPP5D (1)

PAPOLA (1)

SERTAD2 (1)

ERMP1 (1)

C3ORF58 (1)

HNRNPA3P1 (1)
GATA6 (4)

KAT2B (1)

KRAS (3)

NLK (2)

SOX4 (1)
TIMP3 (4)

BCL2 (1)

NLK (2)

BCL2 (1)
MAP3K10 (3) $\quad$ NLK (2)

PLAG1 (2) 
Table 5 | Continued

\begin{tabular}{|c|c|c|c|c|c|c|}
\hline$\frac{\mathbf{m i R}}{\text { hsa-miR-197 }}$ & \multicolumn{6}{|c|}{ Experimentally validated genes } \\
\hline & $\mathrm{CHIC2}(4)$ & ALMS1 (2) & CPNE6 (2) & WDR6 (1) & PEX13 (1) & IL1R1 (1) \\
\hline & RAB28 (3) & ZNF302 (2) & CYLD (2) & PIPOX (1) & MED16 (1) & SNX1 (1) \\
\hline & HNRNPD (2) & RAD51 (2) & RFX1 (2) & IGF2AS (1) & LRP4 (1) & KLF10 (1) \\
\hline hsa-miR-199b & LAMC2 (1) & HES1 (1) & & & & \\
\hline \multirow[t]{2}{*}{ hsa-miR-200c } & ZFPM2 (6) & ZEB1 (5) & ERRFI1 (5) & ZEB2 (5) & FN1 (5) & UBE2I (3) \\
\hline & BAP1 (2) & PTPN13 (1) & BMI1 (1) & JAG1 (1) & TUBB3 (1) & \\
\hline \multirow[t]{2}{*}{ hsa-miR-21 } & TGFBI (5) & GLCCI1 (3) & RASGRP1 (3) & SGK3 (2) & ANKRD46 (2) & SLC16A10 (1) \\
\hline & RTN4 (1) & PTX3 (1) & CDK2AP1 (1) & & & \\
\hline \multirow[t]{2}{*}{ hsa-miR-222 } & CDKN1B (5) & FOS (5) & $\mathrm{KIT}(4)$ & CDKN1C (3) & PPP2R2A (2) & MMP1 (1) \\
\hline & SOD2 (1) & $\mathrm{BBC} 3(1)$ & PTEN (1) & ICAM1 (1) & ESR1 (1) & \\
\hline \multirow[t]{3}{*}{ hsa-miR-24* } & CDKN1B (4) & TRIB3 (4) & MAPK14 (2) & FURIN (2) & BRCA1 (1) & NOTCH1 (1) \\
\hline & ACVR1B (4) & DND1 (3) & NFAT5 (2) & MLEC (2) & KIAA0152 (1) & CDKN2A (1) \\
\hline & KHSRP (1) & HNF4A (1) & TGFB1 (1) & & & \\
\hline \multirow[t]{3}{*}{ hsa-miR-26a } & SMAD1 (5) & HMGA1 (5) & CDK8 (4) & HMGA2 (3) & CCND2 (2) & CCNE2 (2) \\
\hline & STRADB (5) & GSK3B (5) & MTDH (4) & CPEB4 (3) & CTGF (2) & $\operatorname{LIF}(2)$ \\
\hline & PTEN (5) & $\mathrm{EZH} 2(4)$ & MAP3K2 (4) & SERBP1 (2) & CDC6 (2) & CPEB2 (1) \\
\hline hsa-miR-100 & MTOR (3) & PLK1 (1) & FGFR3 (1) & IGF1R (1) & ATM (1) & \\
\hline \multirow[t]{11}{*}{ hsa-miR-125b } & LACTB (6) & BMF (3) & SAMD10 (3) & MKNK2 (2) & BBC3 (2) & DICER1 (1) \\
\hline & BAK1 (5) & BMPR1B (3) & EIF4EBP1 (3) & CBFB (2) & osox2 (2) & JUB (1) \\
\hline & ARID3B (5) & ENTPD4 (3) & KLF13 (3) & LIN28A (2) & LIN28 (1) & DDX19B (1) \\
\hline & IRF4 (5) & TOR2A (3) & ULK3 (3) & IGF2 (2) & C10ORF104 (1) & PABPC1 (1) \\
\hline & PRDM1 (4) & KCNS3 (3) & SLC7A6 (3) & NKIRAS2 (2) & B3GALT4 (1) & AKT1 (1) \\
\hline & SLC35A4 (4) & LIN28B (3) & SLC7A1 (3) & SEL1L (2) & UBE2I (1) & TP53 (1) \\
\hline & CGN (4) & GRIN2A (3) & ERBB3 (2) & ATXN1 (2) & RBM8A (1) & CASC3 (1) \\
\hline & PPAT (4) & STAT3 (3) & CDKN2A (2) & RAF1 (2) & IGFBP3 (1) & E2F3 (1) \\
\hline & CBX7 (3) & $\operatorname{LIF}(3)$ & ABTB1 (2) & CYP24A1 (2) & MAN1A1 (1) & RNF144A (1) \\
\hline & SGPL1 (3) & SMARCD2 (3) & ARID3A (2) & ABCC4 (2) & SMO (1) & LYPLA2 (1) \\
\hline & PLEKHA8 (1) & TP53INP1 (1) & VDR (1) & & & \\
\hline hsa-miR-211 & KCNMA1 (3) & & & & & \\
\hline hsa-miR-302c & ESR1 (2) & & & & & \\
\hline hsa-miR-326 & PKM2 (2) & SMO (1) & GLI1 (1) & NOTCH2 (1) & & \\
\hline hsa-miR-422a** & CYP8B1 (2) & & & & & \\
\hline
\end{tabular}


Table 5 | Continued

\begin{tabular}{|c|c|c|c|c|c|c|}
\hline $\mathrm{miR}$ & & & erimentally va & jenes & & \\
\hline hsa-miR-519d & CDKN1A (4) & PPARA (3) & & & & \\
\hline hsa-miR-520c & APP (3) & CD44 (3) & & & & \\
\hline hsa-miR-520g & VEGFA (2) & & & & & \\
\hline hsa-miR-522 & SOX2 (1) & & & & & \\
\hline hsa-miR-342 & BMP7 (1) & GEMIN4 (1) & & & & \\
\hline hsa-miR-429 & ZFPM2 (6) & ZEB1 (6) & ERRFI1 (4) & ZEB2 (4) & WASF3 (3) & BAP1 (1) \\
\hline
\end{tabular}

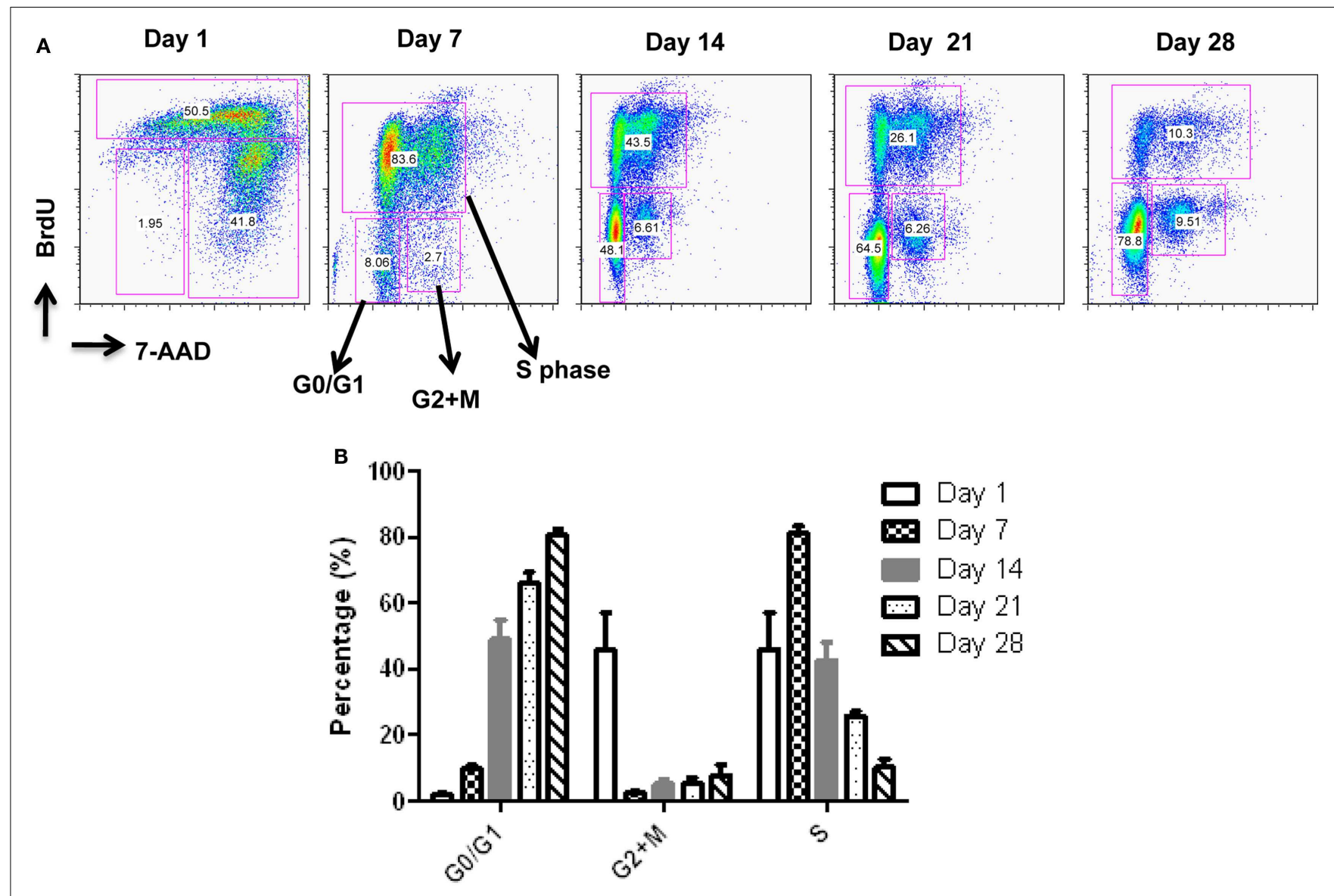

FIGURE 3 | Cell cycle analysis of expanded pNK cells. (A) Representative APC-BrdU/7-AAD cell cycle analysis of ex vivo-expanded pNK at different time points as indicated. (B) Cell cycle analysis at different phases from ex vivo-expanded pNK at different time points as indicated $(n=5)$.

of expanded pNK cells against tumor lines was dose-dependent. Taken together, these results demonstrated that expanded pNKs have the ability to kill a wide variety of tumor cells derived from leukemia and solid tumors.

\section{DISCUSSION}

We have herein described, for the first time, that HPDSC (a product being developed by CCT for hematopoietic reconstitution in hematologic diseases requiring transplant) combined with 
donor-matched UCB, are a novel and rich source of pNK cells. Using a highly robust isolation method, we have achieved large numbers pNK cells in our experiments (approximately $1.5 \times 10^{7}$ cells) from single Combo unit with a high proportion of viable cells $(>70 \%)$, of which approximately $71 \%$ of the population is composed of CD56+CD3 - cells. To overcome the hurdle of limited cell number for NK immunotherapy, we established a 21-day feeder cell-based NK cultivation process. Recently, several groups have successfully shown robust NK cell proliferation using K562 cells expressing 4-1BB Ligand and membrane-bound IL-15 (mbIL-15) or 4-1BB Ligand and mbIL-21 for expansion (Lee et al.,

Table 6 | Optimization of ratio of feeder cells: K562 to PBMC.

\begin{tabular}{lcll}
\hline $\begin{array}{l}\text { Feeder Ratio } \\
\text { (K562:PBMC) }\end{array}$ & Donors $(\boldsymbol{n})$ & $\begin{array}{l}\text { Fold expansion* } \\
\text { range }(\mathbf{m i n}, \mathbf{m a x})\end{array}$ & $\begin{array}{l}\text { Average fold } \\
\text { expansion }\end{array}$ \\
\hline $1: 10$ & 9 & 6,131 & 53 \\
$1: 5$ & 3 & 11,54 & 32 \\
$1: 1$ & 14 & 15,358 & 98
\end{tabular}

*Fold expansion $=$ absolute number of CD56+CD3- NK cells on Day 21/absolute number of NK cells on Day 0.

Table 7 | Effect of feeder replenishing at different time points.

\begin{tabular}{lllc}
\hline $\begin{array}{l}\text { Day of } \\
\text { stimulation }\end{array}$ & Donors $(\boldsymbol{n})$ & $\begin{array}{l}\text { Fold expansion } \\
\text { range (min, max) }\end{array}$ & $\begin{array}{l}\text { Average fold } \\
\text { expansion }\end{array}$ \\
\hline Day 0 & 10 & 17,83 & 41 \\
Day 0 + Day 7 & 10 & 48,395 & 148
\end{tabular}

2010; Denman et al., 2012; Lapteva et al., 2012). Our initial culture optimization utilizing unmodified K562 cells and allogeneic PBMC resulted in an average of $1.2 \times 10^{9}$ cells per donor that were $>80 \%$ CD56+CD3 - and with good consistency across donors. It is conceivable that potential NK cells with higher fold expansion, longer telomere, and less senescence (Denman et al., 2012) can be achieved by switching to genetically modified K562 cells. In addition, Xing et al. (2010) reported that UCB derived NK cells have low cytolytic activity due to impaired lytic immunological synapse formation that can be enhanced by addition of IL-2 during ex vivo expansion. In our study, while uncultured pNK cells showed litthe cytolytic activity against K562 cells, this activity significantly increased after 21 days of ex vivo expansion, and was associated with increased expression of NKG2D, NKp46, NKp44, and several miRNAs.

In recent years, human placenta has emerged as a valuable source of several stem/progenitor cell populations of mesenchymal and hematopoietic origin with therapeutic potential. However, little information is available on the role of pNK cells for cellular immunotherapy. We report here that pNK cells are largely similar to UCB NK cells, both phenotypically and functionally. We can significantly increase the number of feed stock for generating an NK cell-based therapeutic agent by combining NK cells from donor-matched HPDSC and UCB. In attempts to compare gene expression profiles in pNK cells to PB NK cells, we discovered that individual donor variations in gene expression profiles were too large to evaluate differences between the placenta and PB NK sources. As an alternative strategy, we performed analysis of miRNA expression, which appeared to be more consistent across individual donors, to identify profiles that were unique to

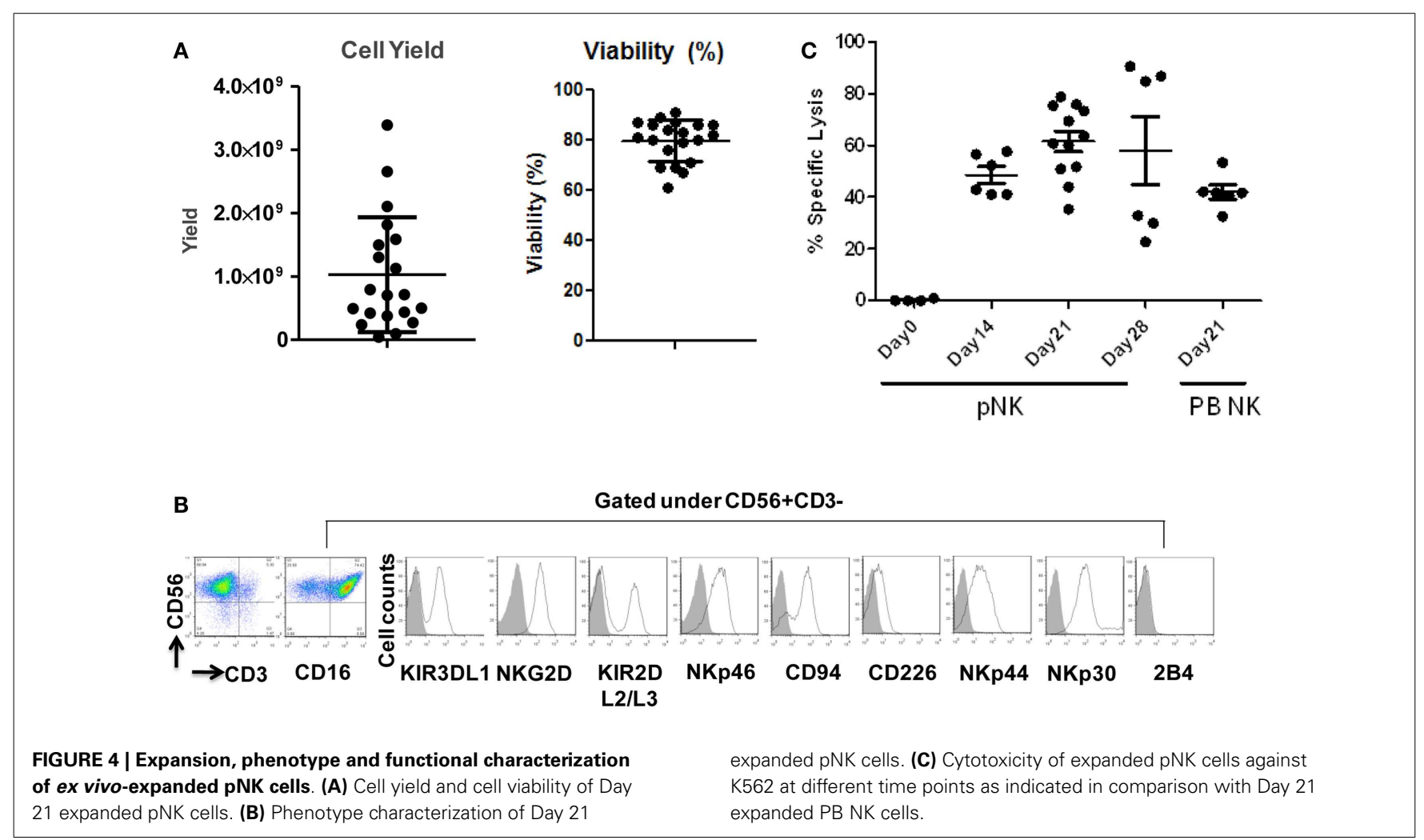


Table 8 | Sub-population comparison of Day 21 expanded pNK versus unexpanded pNK cells.

\begin{tabular}{|c|c|c|c|c|c|}
\hline \multirow{2}{*}{$\begin{array}{l}\text { NK Sub- } \\
\text { populations }\end{array}$} & \multicolumn{2}{|c|}{ Day 21 pNK $(n=12 \mathrm{U})$} & \multicolumn{2}{|c|}{ Day $0 \mathrm{pNK}(n=16 \mathrm{U})$} & \multirow[t]{2}{*}{$p$ Value } \\
\hline & Mean (\%) & SD & Mean (\%) & SD & \\
\hline CD56+CD16- & 35.98 & 18.18 & 60.94 & 16.58 & $* *$ \\
\hline CD56+CD16+ & 63.80 & 18.32 & 39.05 & 16.58 & $* *$ \\
\hline KIR3DL1+ & 17.92 & 13.44 & 12.31 & 8.11 & NS \\
\hline KIR2DL2/L3+ & 21.10 & 10.48 & 21.89 & 8.65 & NS \\
\hline NKG2D+ & 89.28 & 12.88 & 42.11 & 17.79 & $* * *$ \\
\hline NKp46+ & 88.74 & 5.34 & 6.98 & 4.33 & $* * *$ \\
\hline CD226+ & 18.79 & 12.14 & 15.97 & 6.66 & NS \\
\hline NKp44+ & 64.13 & 16.65 & 9.48 & 5.27 & $* *$ \\
\hline NKp30+ & 84.53 & 12.40 & 39.08 & 19.06 & $* * *$ \\
\hline 2B4+ & 0.89 & 0.99 & 11.07 & 5.90 & $* * *$ \\
\hline CD94+ & 74.82 & 12.45 & 71.31 & 13.94 & NS \\
\hline
\end{tabular}

${ }^{*} p<0.05 ;{ }^{* *} p<0.01 ;{ }^{* *} p<0.001$.

Table 9 | Sub-populations comparison in Day 21 expanded pNK versus Day 21 expanded PB NK.

\begin{tabular}{|c|c|c|c|c|c|}
\hline \multirow[t]{2}{*}{ NK sub-populations } & \multicolumn{2}{|c|}{ Combo (12 U) } & \multicolumn{2}{|c|}{ PB (9 U) } & \multirow[t]{2}{*}{$p$ Value } \\
\hline & Mean (\%) & SD & Mean (\%) & SD & \\
\hline CD16- & 35.98 & 18.18 & 28.39 & 7.78 & NS \\
\hline CD16+ & 63.80 & 18.32 & 71.50 & 7.78 & NS \\
\hline KIR3DL1+ & 17.92 & 13.44 & 8.83 & 6.44 & NS \\
\hline KIR2DL2/L3+ & 21.10 & 10.48 & 37.40 & 17.82 & $*$ \\
\hline NKG2D+ & 89.28 & 12.88 & 73.27 & 20.06 & NS \\
\hline NKp46+ & 88.74 & 5.34 & 64.97 & 17.26 & $* *$ \\
\hline CD226+ & 18.79 & 12.14 & 4.80 & 1.72 & NS \\
\hline NKp44+ & 64.13 & 16.65 & 16.00 & 3.82 & $* *$ \\
\hline NKp30+ & 84.53 & 12.40 & 55.77 & 1.96 & $*$ \\
\hline 2B4+ & 0.89 & 0.99 & 2.16 & 1.76 & NS \\
\hline CD94+ & 74.82 & 12.45 & 71.76 & 20.35 & NS \\
\hline
\end{tabular}

${ }^{*} p<0.05 ;{ }^{* *} p<0.01 ;{ }^{* * *} p<0.001$.

pNK or PB NK cells. We identified four unique and 20 highly expressed miRNAs in pNK cells, and eight unique and 29 highly expressed miRNAs in PB NK cells. Target gene prediction analysis returned 14 highly expressed miRNAs in pNK and 24 highly expressed miRNA in PB NK with more than one target gene. In PB NK, highly expressed miRNAs included has-let-7a, has-let$7 \mathrm{~g}$, has-mir-133b, has-mir-181b, and has-mir-181d that target the anti-apoptotic genes Bcl-2 and Bcl-2L, which may indicate that PB NK cells are closer to reaching the limit of cell expansion than pNK cells. Additionally, miRNA hsa-mir-146b is highly expressed in PB NK cells, and its target TRAF6 has been reported to downregulate NF-kB activity, suppress cell proliferation and enhance chemosensitivity (Paik et al., 2011). TRAF6 plays a critical role in innate and adaptive immunity (Chiffoleau et al., 2003) in conjunction with genes such as MAPK14, IL6, and FOS, which are targeted by has-mir-24, has-mir-7a, and has-mir-222 respectively, all found
Table 10 | Differentially regulated miRNAs during pNK ex vivo expansion.

\begin{tabular}{|c|c|c|}
\hline miRNA & Fold change in Day 21 versus Day 0 & $p$ Value \\
\hline hsa-miR-520g & -2820.57 & $6.33 \mathrm{E}-05$ \\
\hline hsa-miR-520h & -2803.02 & $4.35 \mathrm{E}-04$ \\
\hline hsa-miR-518a & -2300.60 & $5.72 \mathrm{E}-05$ \\
\hline hsa-miR-517b & -1669.82 & $8.11 \mathrm{E}-05$ \\
\hline hsa-miR-451 & -1626.65 & $2.40 \mathrm{E}-03$ \\
\hline hsa-miR-518c & -609.88 & $2.93 E-04$ \\
\hline hsa-miR-127 & -557.55 & $3.40 E-04$ \\
\hline hsa-miR-517a & -288.89 & $8.27 \mathrm{E}-05$ \\
\hline hsa-miR-382 & -273.34 & $1.77 \mathrm{E}-04$ \\
\hline hsa-miR-519d & -245.09 & 7.13E-04 \\
\hline hsa-miR-486 & -149.95 & $6.29 E-03$ \\
\hline hsa-miR-518b & -112.10 & $9.70 \mathrm{E}-05$ \\
\hline hsa-miR-522 & -85.30 & $2.58 \mathrm{E}-03$ \\
\hline hsa-miR-376a & -72.14 & $2.95 \mathrm{E}-03$ \\
\hline hsa-miR-198 & -70.93 & 1.13E-03 \\
\hline hsa-miR-126 & -51.46 & $1.97 \mathrm{E}-04$ \\
\hline hsa-miR-487b & -47.68 & $3.32 \mathrm{E}-03$ \\
\hline hsa-miR-519c & -47.52 & $4.88 \mathrm{E}-03$ \\
\hline hsa-miR-518e & -34.89 & $5.06 \mathrm{E}-03$ \\
\hline hsa-miR-433 & -18.07 & $5.68 \mathrm{E}-04$ \\
\hline hsa-miR-125b & -16.66 & $4.66 \mathrm{E}-04$ \\
\hline hsa-miR-214 & -16.38 & $5.74 \mathrm{E}-03$ \\
\hline hsa-miR-130a & -12.98 & $4.13 E-03$ \\
\hline hsa-miR-518d & -10.75 & $8.73 E-03$ \\
\hline hsa-miR-99a & -7.91 & $2.03 \mathrm{E}-03$ \\
\hline hsa-miR-515-3p & -4.93 & $2.50 \mathrm{E}-03$ \\
\hline hsa-miR-95 & -4.73 & $9.30 E-04$ \\
\hline hsa-miR-30a-3p & -3.06 & $1.20 \mathrm{E}-03$ \\
\hline hsa-miR-30d & -2.59 & $4.32 E-03$ \\
\hline hsa-miR-26a & -1.75 & $7.81 E-03$ \\
\hline hsa-miR-191 & -1.32 & $2.12 \mathrm{E}-03$ \\
\hline hsa-miR-331 & 1.53 & $6.74 \mathrm{E}-03$ \\
\hline hsa-miR-181c & 1.71 & $1.24 \mathrm{E}-03$ \\
\hline hsa-miR-142-3p & 2.24 & $5.55 E-03$ \\
\hline hsa-miR-155 & 2.48 & $3.47 E-03$ \\
\hline hsa-miR-24 & 2.66 & $1.03 E-03$ \\
\hline hsa-miR-23a & 3.07 & $8.50 E-03$ \\
\hline hsa-miR-142-5p & 3.21 & $3.34 \mathrm{E}-04$ \\
\hline hsa-let-7d & 3.22 & $3.29 \mathrm{E}-03$ \\
\hline hsa-miR-195 & 3.77 & $2.92 \mathrm{E}-04$ \\
\hline hsa-miR-141 & 3.80 & $5.20 E-03$ \\
\hline hsa-miR-98 & 3.83 & $2.96 \mathrm{E}-03$ \\
\hline hsa-miR-222 & 3.86 & $7.71 \mathrm{E}-03$ \\
\hline hsa-miR-545 & 5.28 & $5.60 E-03$ \\
\hline hsa-miR-642 & 7.17 & $2.82 \mathrm{E}-04$ \\
\hline hsa-miR-21 & 13.46 & $1.94 \mathrm{E}-04$ \\
\hline hsa-miR-210 & 13.87 & $6.66 \mathrm{E}-03$ \\
\hline hsa-miR-221 & 21.73 & $3.04 \mathrm{E}-03$ \\
\hline hsa-miR-34c & 45.37 & $5.26 \mathrm{E}-04$ \\
\hline hsa-miR-135b & 49.26 & 1.17E-03 \\
\hline hsa-miR-34a & 66.38 & $8.08 \mathrm{E}-03$ \\
\hline hsa-miR-10a & 72.27 & $1.27 \mathrm{E}-03$ \\
\hline hsa-miR-380-3p & 921.50 & $1.18 \mathrm{E}-03$ \\
\hline hsa-miR-520a & 10892.33 & $2.38 \mathrm{E}-05$ \\
\hline
\end{tabular}




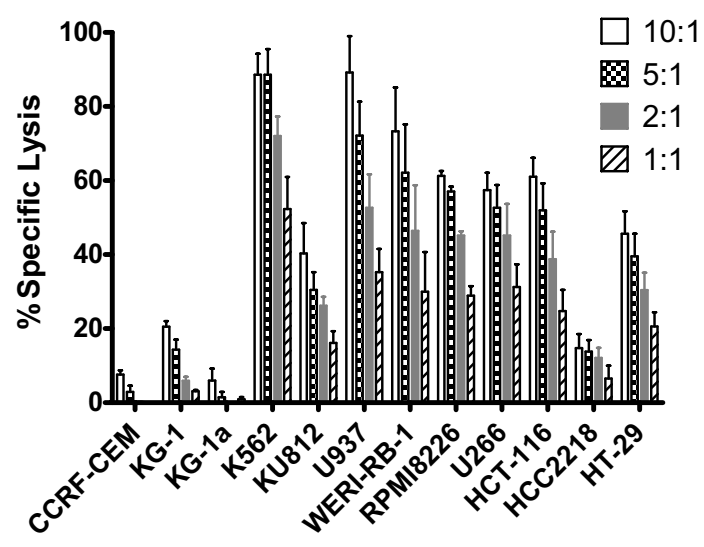

FIGURE 5 | Cytotoxicity of ex vivo-expanded Day 21 pNK cells against a wide range of tumor cell lines. Cytotoxicity of ex vivo-expanded pNK cells $(n=6)$ against a wide range of tumor cell lines at E:T ratio of 10:1, 5:1, $2: 1$, and $1: 1$ as indicated

in our study to be highly expressed in PB NK. Furthermore, we identified a has-mir-181 group (has-mir-181b, has-mir-181c, hasmir-181d) that was threefold higher in PB NK. These miRNAs target nemo-like kinase, a regulator of Notch signaling, which plays an important role in the development of NK cells from

\section{REFERENCES}

Apps, R., Sharkey, A., Gardner, L., Male, V., Kennedy, P., Masters, L., et al. (2011). Ex vivo functional responses to HLA-G differ between blood and decidual NK cells. Mol. Hum. Reprod. 17, 577-586.

Bezman, N. A., Cedars, E., Steiner, D. F., Blelloch, R., Hesslein, D. G., and Lanier, L. L. (2010). Distinct requirements of microRNAs in NK cell activation, survival, and function. J. Immunol. 185, 3835-3846.

Chiffoleau, E., Kobayashi, T., Walsh, M. C., King, C. G., Walsh, P. T., Hancock, W. W., et al. (2003). TNF receptorassociated factor 6 deficiency during hemopoiesis induces Th2-polarized inflammatory disease. J. Immunol. 171, 5751-5759.

Cichocki, F., Felices, M., McCullar, V., Presnell, S. R., Al-Attar, A., Lutz, C. T., et al. (2011). Cutting edge: microRNA-181 promotes human NK cell development by regulating Notch signaling. J. Immunol. 187, 6171-6175.

Cooper, M. A., Fehniger, T. A., and Caligiuri, M. A. (2001). The biology of human natural killercell subsets. Trends Immunol. 22, 633-640.

Curti, A., Ruggeri, L., D’Addio, A., Bontadini, A., Dan, E., Motta, M. R., et al.
(2011). Successful transfer of alloreactive haploidentical KIR ligandmismatched natural killer cells after infusion in elderly high risk acute myeloid leukemia patients. Blood 118, 3273-3279.

Denman, C. J., Senyukov, V. V., Somanchi, S. S., Phatarpekar, P. V., Kopp, L. M., Johnson, J. L., et al. (2012). Membrane-bound IL-21 promotes sustained ex vivo proliferation of human natural killer cells. PLoS ONE 7:e30264. doi:10.1371/journal.pone.0030264

Fehniger, T. A., Cooper, M. A., Nuovo, G. J., Cella, M., Facchetti, F., Colonna, M., et al. (2003). CD56bright natural killer cells are present in human lymph nodes and are activated by $T$ cell-derived IL-2: a potential new link between adaptive and innate immunity. Blood 101, 3052-3057.

Ferlazzo, G., Thomas, D., Lin, S. L., Goodman, K., Morandi, B., Muller, W. A., et al. (2004). The abundant NK cells in human secondary lymphoid tissues require activation to express killer cell Ig-like receptors and become cytolytic. J. Immunol. 172, 1455-1462.

Freud, A. G., Becknell, B., Roychowdhury, S., Mao, H. C., Ferketich, A. K., Nuovo, G. J., et al. (2005). A human CD34(+)

CD34+ HSCs and IFN- $\gamma$ production in primary CD56+ NK cells (Cichocki et al., 2011). Lastly, within the group of highly expressed miRNAs in pNK, we have identified miRNA: mRNA target pairs comprised of pluripotency markers in stem cells and cell cycle regulators, such as SOX2, BMPR1, SMO, AKT1, ATM, RAF1, and MTOR, most of which are not present in the targeted gene list (both experimental and validated) of miRNAs in PB NK. Furthermore, comparison studies have revealed the higher expression of NKp44 and greater cytotoxic activity against K562 at Day 21 $(42 \pm 7 \%)$ from expanded pNK compared to that of expanded PB NK cells.

In conclusion, we have characterized pNK cells from donormatched HPDSC and UCB. pNK cells showed a distinct phenotype and miRNA profile from PB NK cells. We have demonstrated that pNK cells can be readily obtained from Combo units. These cells can be expanded, characterized, and activated to yield clinically relevant quantities of a highly cytotoxic cellular product with potential as a treatment for a wide range of hematological cancers. Taken together, the results presented here provide an important advance in the development of NK cell-based therapeutic products.

\section{ACKNOWLEDGMENTS}

The authors thank Dr. Vivian Albert, Dr. Ellen Baum, Dr. James Edinger, and Dr. George Matcham for reviewing the manuscript and providing critical feedback.

subset resides in lymph nodes and differentiates into CD56bright natural killer cells. Immunity 3, 295-304.

Herberman, R. B., Nunn, M. E., and Lavrin, D. H. (1975a). Natural cytotoxic reactivity of mouse lymphoid cells against syngeneic acid allogeneic tumors. I. Distribution of reactivity and specificity. Int. J. Cancer 16, 216-229.

Herberman, R. B., Nunn, M. E., Holden, H. T., and Lavrin, D. H. (1975b). Natural cytotoxic reactivity of mouse lymphoid cells against syngeneic and allogeneic tumors. II. Characterization of effector cells. Int. J. Cancer 16, 230-239.

Hiby, S. E., Walker, J. J., O’Shaughnessy, K. M., Redman, C. W., Carrington, M., Trowsdale, J., et al. (2004). Combinations of maternal KIR and fetal HLA-C genes influence the risk of preeclampsia and reproductive success. J. Exp. Med. 200, 957-965.

Huntington, N. D., Vosshenrich, C. A., and Di Santo, J. P. (2007). Developmental pathways that generate natural killer-cell diversity in mice and humans. Nat. Rev. Immunol. 7, 703-714.

Jacobs, R., Hintzen, G., Kemper, A., Beul, K., Kempf, S., Behrens, G., et al. (2001). CD56bright cells differ in their KIR repertoire and cytotoxic features from CD56dim NK cells. Eur. J. Immunol. 31, 3121-3127.

Koopman, L. A., Kopcow, H. D., Rybalov, B., Boyson, J. E., Orange, J. S., Schatz, F., et al. (2003). Human decidual natural killer cells are a unique NK cell subset with immunomodulatory potential. J. Exp. Med. 198, 1201-1212.

Kopcow, H. D., Allan, D. S., Chen, X., Rybalov, B., Andzelm, M. M., Ge, B., et al. (2005). Human decidual NK cells form immature activating synapses and are not cytotoxic. Proc. Natl. Acad. Sci. U.S.A. 102, 15563-15568.

Kopcow, H. D., Eriksson, M., Mselle, T. F., Damrauer, S. M., Wira, C. R., Sentman, C. L., et al. (2010). Human decidual NK cells from gravid uteri and $\mathrm{NK}$ cells from cycling endometrium are distinct NK cell subsets. Placenta 31, 334-338.

Lanier, L. L., Le, A. M., Civin, C. I., Loken, M. R., and Phillips, J. H. (1986). The relationship of CD16 (Leu-11) and Leu-19 (NKH-1) antigen expression on human peripheral blood NK cells and cytotoxic $\mathrm{T}$ lymphocytes. J. Immunol. 136, 4480-4486. 
Lapteva, N., Durett, A. G., Sun, J., Rollins, L. A., Huye, L. L., Fang, J., et al. (2012). Large-scale ex vivo expansion and characterization of natural killer cells for clinical applications. Cytotherapy 14, 1131-1143.

Lee, D. A., Verneris, M. R., and Campana, D. (2010). Acquisition, preparation, and functional assessment of human NK cells for adoptive immunotherapy. Methods Mol. Biol. 651, 61-77.

Lee-MacAry, A. E., Ross, E. L., Davies, D., Laylor, R., Honeychurch, J., Glennie, M. J., et al. (2001). Development of a novel flow cytometric cellmediated cytotoxicity assay using the fluorophores PKH-26 and TOPRO-3 iodide. J. Immunol. Methods 252, 83-92.

Livak, K. J., and Schmittgen, T. D. (2001). Analysis of relative gene expression data using real-time quantitative PCR and the 2(-Delta Delta C(T)). Methods 4, 402-408.

Male, V., Sharkey, A., Masters, L., Kennedy, P. R., Farrell, L. E., and Moffett, A. (2011). The effect of pregnancy on the uterine NK cell KIR repertoire. Eur. J. Immunol. 41, 3017-3027.

McKenna, D. H. Jr., Sumstad, D., Bostrom, N., Kadidlo, D. M., Fautsch, S., McNearney, S., et al. (2007). Good manufacturing practices production of natural killer cells for immunotherapy: a six-year single-institution experience. Transfusion 47, 520-528.

Meyer-Monard, S., Passweg, J., Siegler, U., Kalberer, C., Koehl, U., Rovó, A., et al. (2009). Clinical-grade purification of natural killer cells in haploidentical hematopoietic stem cell transplantation. Transfusion 49, 362-371.

Miller, J. S., Soignier, Y., PanoskaltsisMortari, A., McNearney, S. A., Yun, G. H., Fautsch, S. K., et al. (2005). Successful adoptive transfer and in vivo expansion of human haploidentical NK cells in patients with cancer. Blood 105, 3051-3057.

Paik, J. H., Jang, J. Y., Jeon, Y. K., Kim, W. Y., Kim, T. M., Heo, D.
S., et al. (2011). MicroRNA-146a downregulates NFKB activity via targeting TRAF6 and functions as a tumor suppressor having strong prognostic implications in NK/T cell lymphoma. Clin. Cancer Res. 17, 4761-4771.

Parolini, O., Alviano, F., Bagnara, G. P., Bilic, G., Bühring, H. J., Evangelista, M., et al. (2008). Concise review: isolation and characterization of cells from human term placenta: outcome of the first international Workshop on Placenta Derived Stem Cells. Stem Cells 26, 300-311.

Passweg, J. R., Tichelli, A., MeyerMonard, S., Heim, D., Stern, M., Kühne, T., et al. (2004). Purified donor NK-lymphocyte infusion to consolidate engraftment after haploidentical stem cell transplantation. Leukemia 18, 1835-1838.

Prather, W. R., Toren, A., and Meiron, M. (2008). Placental-derived and expanded mesenchymal stromal cells (PLX-I) to enhance the engraftment of hematopoietic stem cells derived from umbilical cord blood. Expert Opin. Biol. Ther. 8, 1241-1250.

Rubnitz, J. E., Inaba, H., Ribeiro, R. C. Pounds, S., Rooney, B., Bell, T., et al. (2010). NKAML: a pilot study to determine the safety and feasibility of haploidentical natural killer cell transplantation in childhood acute myeloid leukemia. J. Clin. Oncol. 28, 955-959.

Ruggeri, L., Capanni, M., Casucci, M., Volpi, I., Tosti, A., Perruccio, K., et al. (1999). Role of natural killer cell alloreactivity in HLA-mismatched hematopoietic stem cell transplantation. Blood 94, 333-339.

Ruggeri, L., Capanni, M., Urbani, E., Perruccio, K., Shlomchik, W. D., Tosti, A., et al. (2002). Effectiveness of donor natural killer cell alloreactivity in mismatched hematopoietic transplants. Science 295, 2097-2100.

Shi, J., Tricot, G., Szmania, S., Rosen, N., Garg, T. K., Malaviarachchi, P. A., et al. (2008). Infusion of haploidentical killer immunoglobulinlike receptor ligand mismatched NK cells for relapsed myeloma in the setting of autologous stem cell transplantation. Br. J. Haematol. 143 641-653.

Smyth, M. J., Hayakawa, Y., Takeda, K., and Yagita, H. (2002). New aspects of natural-killer-cell surveillance and therapy of cancer. Nat. Rev. Cancer 2, 850-861.

Spanholtz, J., Tordoir, M., Eissens, D., Preijers, F., van der Meer, A., Joosten, I., et al. (2010). High log-scale expansion of functional human natural killer cells from umbilical cord blood CD34-positive cells for adoptive cancer immunotherapy. PLoS ONE 5:e9221. doi:10.1371/journal.pone.0009221

Sutlu, T., and Alici, E. (2009). Natural killer cell-based immunotherapy in cancer: current insights and future prospects. J. Intern. Med. 266 , 154-181.

Trotta, R., Chen, L., Ciarlariello, D. Josyula, S., Mao, C., Costinean, S., et al. (2012). miR-155 regulates IFN$\gamma$ production in natural killer cells. Blood 119, 3478-3485.

Velardi, A., Ruggeri, L., Moretta, A., and Moretta, L. (2002). NK cells: a lesson from mismatched hematopoietic transplantation. Trends Immunol. 23, 438-444.

Woll, P. S., Grzywacz, B., Tian, X., Marcus, R. K., Knorr, D. A., Verneris, M. R., et al. (2009). Human embryonic stem cells differentiate into a homogeneous population of natural killer cells with potent in vivo antitumor activity. Blood 113, 6094-6101.

Xing, D., Ramsay, A. G., Gribben, J. G. Decker, W. K., Burks, J. K., Munsell, M., et al. (2010). Cord blood natural killer cells exhibit impaired lytic immunological synapse formation that is reversed with IL-2 ex vivo expansion. J. Immunother. 33, 684-696.

Yoon, S. R., Lee, Y. S., Yang, S. H., Ahn, K. H., Lee, J. H., Lee, J. H., et al. (2010) Generation of donor natural killer cells from CD34(+) progenitor cells and subsequent infusion after HLAmismatched allogeneic hematopoietic cell transplantation: a feasibility study. Bone Marrow Transplant. 45, 1038-1046.

Yssel, H., de Vries, J. E., Koken, M., Van Blitterswijk, W., and Spits, H. (1984). Serum-free medium for the generation and propagation of functional human cytotoxic and helper $\mathrm{T}$ cell clones. J. Immunol. Methods 72, 219-227.

Zhong, N., Sun, J., Min, Z., Zhao, W., Zhang, R., Wang, W., et al. (2012). MicroRNA-337 is associated with chondrogenesis through regulating TGFBR2 expression. Osteoarthr. Cartil. 6, 593-602.

Conflict of Interest Statement: Lin Kang, Vanessa Voskinarian-Berse, Eric Law, Tiffany Reddin, Mohit Bhatia, Yuhong Ning, Wolfgang Hofgartner, Stewart Abbot, Xiaokui Zhang, and Robert Hariri hold Celgene employment, equity ownership, and patents; David Dong, Timothy Maguire, and Martin Yarmush have received research funding from Celgene.

Received: 16 February 2013; accepted: 17 April 2013; published online: 01 May 2013.

Citation: Kang L, Voskinarian-Berse V, Law E, Reddin T, Bhatia M, Hariri A, Ning Y, Dong D, Maguire T, Yarmush $M$, Hofgartner $W$, Abbot S, Zhang X and Hariri $R$ (2013) Characterization and ex vivo expansion of human placentaderived natural killer cells for cancer immunotherapy. Front. Immunol. 4:101. doi: 10.3389/fimmu.2013.00101

This article was submitted to Frontiers in NK Cell Biology, a specialty of Frontiers in Immunology.

Copyright (c) 2013 Kang, VoskinarianBerse, Law, Reddin, Bhatia, Hariri, Ning, Dong, Maguire, Yarmush, Hofgartner, Abbot, Zhang and Hariri. This is an open-access article distributed under the terms of the Creative Commons Attribution License, which permits use, distribution and reproduction in other forums, provided the original authors and source are credited and subject to any copyright notices concerning any third-party graphics etc. 